DOI 10.18551/rjoas.2021-04.05

\title{
URGENCY OF THE ETHICS COURT IN ENFORCEMENT CODE OF ETHICS FOR PROFESSION IN INDONESIA
}

\author{
Achsoni Rudhi \\ Doctoral Student, University of Brawijaya, Malang \& Lecturer, University of Muhammadiyah \\ Maluku Utara, Indonesia
}

Istislam, Suryokumoro Herman, Widiarto Aan Eko, Associate Professors

University of Brawijaya, Malang, Indonesia

*E-mail: rudiachsoniii@yahoo.com

\begin{abstract}
Enforcement of professional code of ethics in Indonesia does not work effectively because of problems, ranging from hanging structural institutions, closed enforcement methods, enforcement agencies caught in conflicts of interest, enthusiasm to protect peers, and the work of ethics enforcement agencies that are not has a binding power, resulting in a low level of awareness to comply with the professional code of ethics. The author offers that in the future it is necessary to improve the enforcement of the professional code of ethics through the establishment of the Ethics Court. Through the existence of an Ethics Court, the enforcement of the code of ethics is carried out by using judicial principles, starting from the principles of openness, imparsility, independence, accountability, providing a fair opportunity for parties suspected of violating the code of ethics to prove in court, as well as at the end of the product issued in the form of a judgment which has definite binding power. So that the future enforcement of the professional code of ethics can run effectively.
\end{abstract}

\section{KEY WORDS}

Urgency, ethics court, professional code, ethics.

The effectiveness of upholding the code of ethics by ethical institutions is an interesting phenomenon to research, because in reality the author observes that the application of a code of ethics in a profession is only ceremonial and performance, in the sense that enforcement of the code of ethics is not actually implemented, so that for some people the issue of code of ethics is only seen as an individual matter which is privacy in nature, and to this phenomenon the author is one of those who disagree.

According to Abdul Kadir Muhammad, the code of ethics functions for 3 (three) reasons, first is as a means of social control, second is as a deterrent to interference from other parties, and third is as a prevention of misunderstanding and conflict. ${ }^{1}$ The professional code of ethics has determined the standards for professional obligations of group members who belong to or are members of the profession, and with this code of ethics it is hoped that people who are members of the profession can comply with it, and with the existence of a code of ethics there are 2 (two) basic things will benefit the profession, first, that the profession in question can maintain its honor and the two professions maintain its integrity. Jimly Asshiddiqie said that prior to the existence of a professional code of ethics that was functioned to maintain the honor and integrity of the profession, actually long ago there were already forms of pitutur, rhymes, utterances and tembang-tembang in which there were contents or contents that contains ethical principles, which can provide direction and guidance to do good ${ }^{2}$. These pituturs, as well as utterances, can be found in many local traditions, as well as in villages that are located in remote parts of the country.

\footnotetext{
${ }_{1}^{1}$ Abdul Kadir Muhammad, Etika Profesi Hukum, PT. Citra Aditya Bakti, Bandung, 2001, hlm. 78.

2 Jimly Asshiddiqie, Peradilan Etik and Etika Konstitusi, Sinar Grafika, Jakarta, 2010, hlm.151.
} 
The author observes that in a community tradition that has a high level of awareness, the application of a code of ethics does not necessarily involve an official institution that is credible and has a definite binding power, because without an official institution people who have this profession already have the awareness that they are not allowed to commit violations. code of Ethics. However, in a community tradition where the level of awareness is still low, the existence of a credible institution that has a definite binding power is important. Not to mention the problem of perspective in the profession in seeing the code of ethics as something that is privacy in nature, so that from that point of view it causes the solution to be sufficiently closed. Even though the solution is done in an open way, it doesn't often cause problems, especially in a closed way, and at the end of the ethical settlement process, the products released from the ethical institution also do not have a definite binding power, so that from the sequence of problems it becomes not strange when people starting to doubt and even apathy with the enforcement of the code of ethics of the profession today.

Starting from the brief introduction above, the writer considers that there are problems regarding the enforcement of the professional code of ethics, of the most fundamental problems according to the author are the problems with the institutions that are in charge of enforcing it, starting from the way of enforcing it in a closed manner, the enforcing institutions are trapped in a conflict of interest. , the spirit to protect colleagues, as well as the work of an ethical institution that does not have binding power, resulting in a low level of awareness to comply with the professional code of ethics. The author observes that in the future it is necessary to improve the enforcement of the professional code through the establishment of the Ethics Court, it is hoped that through the Ethics Court the issue of upholding the professional code of ethics can be elaborated, at that point the author is interested in examining the urgency of the Ethics Court in upholding the professional code of ethics in Indonesia.

Problem Formulation. What is the urgency of establishing an Ethics Court in Indonesia?

\section{METHODS OF RESEARCH}

This research is a normative legal research, the function of legal research is to obtain the truth of coherence, ${ }^{3}$ namely looking for the conformity between something to be investigated with the rules or principles that are used as a reference. ${ }^{4}$ The approach used in this research is a constitutional approach and a conceptual approach ${ }^{5}$. The legal materials used were primary, secondary, and tertiary which were analyzed using normative / prescriptive analysis.

\section{RESULTS AND DISCUSSION}

Ethics is literally a language derived from the Greek ethos which means customs. The word ethos has a meaning equivalent to motion in Latin which also means "customs". 6 Meanwhile, Abdul Wahib and Mohammad Muhibin added that ethics is not only a habit or custom but also morals, character, feelings and attitudes, including ways of thinking. ${ }^{7}$

In general, ethics or ethict is a branch of philosophy that discusses right and good behavior in human life. Ethical philosophy is not only concerned with issues of right and wrong such as philosophy of law, but more than that of good and bad. The main objective is the good life (the good life), but in practice, both are related to the substance which is the essence of ethical issues, namely right and wrong as well as good and bad human behavior

\footnotetext{
${ }^{3}$ Peter Mahmud Marzuki, Pengantar Ilmu Hukum, Kencana Prenada Media Group, Jakarta, 2008, hlm.47.

4 Johny Ibrahim, Teori and Metodologi Penelitian Hukum Normatif, Malang Banyumedia Publish, 2006, hlm. 57.

${ }^{5}$ Peter Mahmud Marzuki, Penelitian Hukum, Prenada Media Group, Jakarta, 2016, hlm. 133.

${ }^{6}$ E. Sumaryono, Etika Profesi Hukum, Kanisius, Yogyakarta, 1995, hlm. 12.

7 Abdul Wahid, Moh Muhibin, Etika Profesi Hukum Rekonstruksi Citra Peradilan di Indonesia, Bayu Media Publishing, Malang, 2009, hlm. 19.
} 
in life together. ${ }^{8}$ Then based on this explanation the question arises about how is the relationship between law and ethics.

The discussion of law and ethics has long surfaced, and many opinions often contradict when discussing which one is more urgent and first, between law and ethics or morality. Yovita A. Mangesti and Bernrd L. Tanya stated that ethical or moral law is the need of mankind, it is further stated that without moral law there will be no society that can develop and even survive in peace and justice. ${ }^{9}$ According to him, moral law is both the foundation and the glue that can prevent society from being threatened with disintegration.

The application of ethics in its development according to the author can not only be placed as an abstract norm system that we only know through sermons and religious pulpits, but also as a more concrete norm system for the interest of controlling and directing the behavior of citizens of a community or members of an organization towards values. -values of the common good. In the past, law was not a system of norms that was usually written in the form of laws as it is today, according to history the new legal norm system was written in the form of norms after mankind became familiar with the tradition of reading and writing, and the emergence of a more concrete need to regulate behavior. life together in society and within the framework of state organizations.

Similar developments are experienced by the system of ethical norms, from habits that grow in unwritten life practices, or by simply referring to religious scriptures, over time there is a need to write down ethical principles in the form of codes of ethics and code of conduct. which is concrete and can be used as a means of controlling and guiding ideal behavior in life together.

Based on the author's research, the effectiveness of the ethical system in a profession, whatever the profession so far is still constrained by at least two things, first, namely the ethics enforcement agency itself which lacks authority (minus respect), the enforcement of the code of ethics that is being carried out is currently experiencing problems, starting from the method of enforcement which is carried out in a closed manner, the enforcing institution is trapped in a conflict of interest, the spirit to protect colleagues, and the work of an ethical institution that does not have binding power. So far, most of the products of ethical institutions only end in recommendations, where these recommendations do not have the power to compel, so that in practice the ethical institutions have not run optimally.

The second problem is the obstacle where the ethical system still depends on individual awareness, someone who violates ethics by some circles only means violating the conscience, ${ }^{10}$ so that no concrete sanctions are born. In the author's view, at least these two things have contributed to the low level of compliance with the products issued by these ethics enforcement agencies.

In line with this view, Suparman Marzuki ${ }^{11}$ said that the supervisory institutions created to maintain and enforce ethics have not been able to work optimally with various obstacles, starting from a weak legal basis, hanging structural independence and cultural issues. Starting from this view, the authors are of the view that first the structural independence of ethical code enforcers must be a top priority, and the ethical system should not also be dependent on individual consciousness, because such phenomena have caused the ethical system to not run properly, even in some cases deadlocked. For a country with a high level of awareness, the ethical system does not need to bring coercion, but for a country with a low level of awareness, according to the author, the compulsion of the ethical system is important, because in general to be at a good level of awareness people need the involvement of the state to provide definite binding power regarding violations of the professional code of ethics. In this context, the authors are of the view that it is necessary to establish an Ethics Court, so that enforcement of the code of ethics is carried out by applying judicial principles.

\footnotetext{
8 Jimly Asshiddiqie, Peradilan Etik and Etika Konstitusi, op., cit, hlm. 42.

${ }^{9}$ Yovita A. Mangesti and Bernrd L Tanya, Moralitas Hukum, Genta Publishing, Yogyakarta 2014, hlm. 25.

10 Sudikno Mertokusumo, Mengenal Hukum, Liberty, Yogyakarta, 1996, hlm. 38.

11 Suparman Marzuki, Dalam Buku Menggagas Peradilan Etik di Indonesia, Sekretaris Jendral Komisi Yudisal Republik Indonesia, Jakarta, 2015, hlm. 113.
} 
The idea of an Ethics Court is important and requires more attention, because this idea is in the context of equalizing 2 (two) systems, namely the legal system and the ethical system. Where in the legal system building is found the main basis is the principle of rule of law, which is then implemented in practice the rule of law on the basis of the code of law or the book of laws, and the task of enforcing there is a mechanism known as court of law (court of law). So that based on the building in the legal system, the building model in the ethical system should start with the understanding that there are principles known as rules of ethics, so that as a guideline for these principles a code of ethics is needed, or a code of ethics that has been positivated to become a rule of ethics, as well as in enforcement, a court of ethics is needed, so that based on the argument, the code of ethics is not only a decoration, but there is a real emphasis and sanctions if there is a profession that violates it.

The author is of the view that the idea of an Ethics Court is important, because in fact in the 1945 Constitution the values contained are not only legal values, but also ethical values are very strong. Jimly Asshiddiqie in an interview with the author said that, the 1945 Constitution of the Republic of Indonesia Post-amendments not only regulates legal matters but also includes ethical aspects that surround it, ethical aspects after amendments to the 1945 Constitution of the Republic of Indonesia, among others, can be found in Article 31 paragraph (3) and 31 paragraph (5) of the 1945 Constitution of the Republic of Indonesia, then Article 7 A of the 1945 Republic of Indonesia Constitution, as well as in the constitution there are also regulations regarding the oath of office regulated in Article 9 of the 1945 Republic of Indonesia Constitution. ${ }^{12}$

Article 7 A, Article 9, Article 31 paragraph (3) and 31 paragraph (5) of the 1945 Constitution of the Republic of Indonesia according to the author is quite clear to show that the constitution of the Republic of Indonesia not only regulates a system of values and norms that are legal in nature, but also contains a system. ethical values and norms. Thus, it is advisable to develop a new perspective in the study of constitutional law and specifically the study of the constitution, in addition to constitutional law and constitutional ethics with an equal position in the constitution of a country.

Enforcement of the rule of law in Indonesia is equipped with adequate facilities, starting with the existence of law enforcement officials, the police, the prosecutor's office, to the judiciary. A different thing is found where ethical principles have been placed only as performance, which is manifested in the form of a code of conduct, and this code of conduct is not equipped with an independent enforcement agency, so that in the implementation stage the establishment and upholding of a code of ethics is more caused by the awareness factor of the person. who hold the profession, and when discussing the issue of awareness, the discussion will return to the discussion of belief or religion, so that according to the author's view that the effectiveness of ethical principles today is greatly influenced by the level of one's faith or theological level.

In the sense that when someone has a high level of faith and high spiritual values, then it can be ascertained that the professional code of ethics will work well there, but if the opposite happens, where someone who is holding a profession has a problem with his faith level, then there is a tendency for that person to be ignorant. He must guide the actual code of ethics, because for him to obey or want to be indifferent to the code of ethics, both have no effect or there are no real sanctions.

With regard to legal instruments and ethical instruments as described above, the author finds relevant views regarding the differences in how law and ethics work. Hans Kelsen $^{13}$ in the general theory of law and the state, they discuss the relationship between law, morality and religion, where law, morality and religion prohibit killing. However, the law has its own way of prohibiting such murder, namely by stipulating in the law that if a person

\footnotetext{
12 Ketua DKPP RI Periode 2012 - 2017, Pemerhati Hukum Tata Negara, wawancara dilaksanakan di kantor Jilmy School, Jl. MH. Thamrin, hari senin tanggal 24 bulan februari, tahun 2020.

${ }^{13}$ Hans Kelsen, Teori Umum Tentang Hukum and Negara, terjemahan dari buku asli dengan judul General teory of law and state (New York: Russel and Russel, 1971), Penerjemah Raisul Muttaqien, Bandung, Nusa Media, 2013. hal. 25.
} 
commits a murder then another person appointed by law will apply against the murderer a certain forced act stipulated by legal regulations.

On the other hand, morality has its own way of working where morality limits itself to the necessity where one should not kill, in the event that someone violates it, then the person who kills will be morally ostracized by the environment in which the killer lives. Observing this, in this case the legal norms are closer to religious norms than moral norms, only the difference between religious norms is to threaten the murderer with punishment by God's authority, so that the sanctions established by religious norms have a transcendental character, these sanctions are not carried out by society, although determined by religious regulations, so that the effectiveness of these religious sanctions requires belief in the existence and authority of God.

Based on the description above, a common thread can be drawn that the legal system has a credible institution to enforce the law to be enforced, while morality and religion do not have a credible institution to enforce it, in this case the code of ethics of a profession is similar, in implementation it is not equipped with an independent instrument, so that its effectiveness really depends on the level of awareness of the individual. Therefore the institutionalization of ethical institutions in this case is the establishment of an Ethics Court as part of an effort to enforce the code of ethics no longer depending on individual awareness, but there is an Ethics Court that is ready to enforce it when the code of conduct embodied in the Code of Ethics is violated.

The code of ethics enforcement model is ineffective because it is not accompanied by a strong enforcement agency, which has the authority to impose strict sanctions if ethical norms are violated. The author is of this view because in fact in 2001 the People's Consultative Assembly (MPR) issued MPR Decree No. VI / MPR / 2001 on the ethics of national life, in the MPR TAP regulates that the ethics of national life is a formula that comes from religious teachings, especially those that are universal. and the noble values of the nation's culture which are reflected in Pancasila as the basic reference in thinking, behaving and behaving in the life of the nation. Furthermore, in the MPR TAP, the formulation on ethics of national life was prepared with the aim of helping to provide awareness about the importance of upholding ethics and morals in national life, as well as the goal so that government administrators at all levels, including citizens, have basic references to improve the quality of human beings. have faith, piety and have a noble character and have an Indonesian personality in the life of the nation.

The author observes the fact that the TAP MPR No VI / MPR / 2001 regarding the ethics of national life is only a decoration, because in practice the things that are regulated are not implemented, even though until now TAP MPR No VI / MPR / 2001 on the ethics of national life is still valid, because it has never been revoked.

Starting from the description of the ineffectiveness of TAP MPR No VI / MPR / 2001 regarding the ethics of national life, the author is of the view that ethical principles that come from religious teachings and the noble values of Indonesian culture are not enough to be used as decoration, but must accompanied by a credible enforcement institution, in that context the establishment of an Ethics Court is a necessity. Because the regulation of ethical principles is not accompanied by an ethical court, it will only deliver ethical principles as mere decoration or performance. Why is the author optimistic that in order to make ethical principles more effective, the establishment of an Ethics Court is because the author has made observations, for example the enforcement of the election organizers' code of ethics carried out by the Election Organizer Honorary Council (DKPP) looks quite effective, this is because the way DKPP works is different from the way code of conduct enforcers work in general, one of which is DKPP using trial principles, then litigating parties are given equal opportunities in court (audi et alteram partem), and institutionally DKPP is an independent institution, and products issued are decisions that have force force.

The author observes that the DKPP institutional design has been free from structural independence issues, and in the opinion of the author, DKPP is a good pilot project in an effort to build an Ethics Court going forward, where enforcement of the code of ethics is not 
left to institutions that are internal to the institution where the code of conduct will be enforced, because the model has a real conflict of interest.

The existence of DKPP with all the powers it has in law. No. 7 of 2017 concerning General Elections, is part of the awareness of lawmakers on the problem of ineffective enforcement of the election management code of ethics, so that in this context the authority to enforce the code of ethics by means of a trial owned by DKPP, starting from the authority to listen and Providing equal opportunities for disputing parties (audi at aleteram partem), the authority to present witnesses from the parties, present experts, verify evidence as well as types of legal products in the form of decisions (verdicts) are forms of scientific innovation that can be legally justified.

Whereas then there is a view that the establishment of an ethical court will clash with the standard of the Indonesian legal system. This is a common thing in the scientific world, because the idea of an Ethics Court is something new, so that according to the author over time it will be understood, for example the establishment of the Constitutional Court (MK), first appeared in 2003, there are not a few legal experts. who opposed it with various arguments, especially when the Constitutional Court issued a decision which was conditional in nature (conditionaly constitutional). In the legal system, the authors consider that the views that do not agree on the establishment of the Ethics Court are in the same condition when people considered the first Constitutional Court to be born.

Including the existence of DKPP by applying trial principles, as well as at the end of the session issuing a product called a verdict (verdict), is also not free from criticism, because for those who disagree an institution whose nomenclature uses the phrase "agency", "commission" or " The council "cannot issue a legal product in the form of a decision (verdict). According to the author, this view must be respected, because this view also has a basis, but it would be inappropriate if this view was the only guideline in evaluating. Because the judicial system in Indonesia is currently undergoing a process of structural differentiation, decentralization, deconcentration and even widespread institutional deconstruction. ${ }^{14}$. The causes include the problems and dynamics of the state administration which continue to develop, so that from the dynamics and problems of the rapid development of the state administration, in the end, it has increased the workload of the existing judicial institutions. Because of the presence of institutions such as the Central Information Commission (KIP), the Business Competition Settlement Commission (KPPU), and the Election Supervisory Agency (Bawaslu) are present to reduce the burden on the Court and help bring justice to justice seekers.

The author examines the authority of a body, commission or council to carry out judicial functions, and at the end of issuing a legal product called a decision (verdict), has entered and is accepted in the constitutional system in Indonesia. For example, in an election process dispute handled by Bawaslu ${ }^{15}$, which includes disputes between one participant and other election participants, as well as disputes between election participants and election organizers as a result of the issuance of KPU decisions, Provincial KPU decisions, Regency / City KPU decisions, legal products issued by Bawaslu are called decisions (verdicts), and Bawaslu exercises the authority by holding a trial.

Based on the above argumentation sequence, the writer affirms the view that the idea of establishing an Ethics Court in upholding the professional code of ethics is a necessity of the times. Because based on the arguments that have been made, a common thread is drawn that the rule of law is running and effective because it is supported by good legislation (code of law), and is enforced by a credible and well-founded law enforcer (court of law), so that according to the author's opinion in order to make the ethical system effective, the rules of ethics must be well and comprehensively compiled in the code of ethics, and in the enforcement stage, an Ethics Court must credible and independent (court of etict).

\footnotetext{
${ }^{14}$ Jimly Asshiddiqie, Putih Hitam Pengadilan Khusus, Sekretaris Jendral Komisi Yudisial Republik Indonesia, Jakarta, 2013 hlm. 22.

${ }_{15}$ Pasal 466 Undang-Undang Nomor 7 tahun 2017 tentang Pemilihan Umum.
} 


\section{CONCLUSION}

The current enforcement of professional code of ethics is experiencing problems, especially the problem of structural independence, this problem then implies that the ethical system cannot work effectively, because the institutions that enforce it are trapped in a conflict of interest, the enthusiasm to protect colleagues, and the work results of the institution. ethics that do not have binding power, resulting in a low level of awareness to comply with the professional code of ethics.

Based on this problem, the establishment of an Ethics Court is a solution offered, hoping that with the presence of the Ethics Court, the settlement of the professional code of ethics can be carried out using judicial principles, starting from the principles of openness, imparsility, independence, accountability, and providing fair opportunities for a party suspected of having violated the code of ethics to prove it in court, as well as at the end of the product that is issued in the form of a verdict (verdict) which has force. So that the enforcement of the professional code of ethics in the future will not stagnate due to problems of how ethical institutions work and the problem of low individual awareness.

\section{REFERENCES}

1. Abdul Wahid, Moh Muhibin, Legal Professional Ethics of Judicial Image Reconstruction in Indonesia, Bayu Media Publishing, Malang, 2009.

2. Abdul Kadir Muhammad, Legal Professional Ethics, PT. Citra Aditya Bakti, Bandung, 2001.

3. Sumaryono E. Legal Professional Ethics, Kanisius, Yogyakarta, 1995.

4. Hans Kelsen, General Theory of Law and State, translation of the original book entitled General theory of law and state (New York: Russel and Russel, 1971), Translator Raisul Muttaqien, Bandung, Nusa Media, 2013.

5. Jimly Asshiddiqie, Constitutional Ethics and Ethics Court, Sinar Grafika, Jakarta, 2016.

6. Jimly Asshiddiqie, Putih Hitam Special Court, Secretary General of the Judicial Commission of the Republic of Indonesia, Jakarta, 2013.

7. Johny Ibrahim, Normative Law Research Theory and Methodology, Malang Banyumedia Publish, 2006.

8. Peter Mahmud Marzuki, Introduction to Legal Studies, Kencana Prenada Media Group, Jakarta, 2008.

9. Peter Mahmud Marzuki, Legal Research, Prenada Media Group, Jakarta, 2016.

10. Sudikno Mertokusumo, Knowing the Law, Liberty, Yogyakarta, 1996,

11. Suparman Marzuki, In a book on the idea of an ethical trial in Indonesia, Secretary General of the Judicial Commission of the Republic of Indonesia, Jakarta, 2015.

12. Yovita A. Mangesti and Bernrd L Tanya, Morality of Law, Genta Publishing, Yogyakarta 2014.

13. The 1945 Constitution of the Republic of Indonesia.

14. TAP MPR No VI / MPR / 2001 concerning Ethics of National Life.

15. UU. No. 7 of 2017 concerning General Elections. 